DOI: 10.12731/2070-7568-2017-4-58-68

УДК 327.7

\title{
ТУРИЗМ КАК ПОЛИТИЧЕСКИЙ МЕЖГОСУДАРСТВЕННЫЙ ДИАЛОГ
}

\section{Матвеевская А.C.}

Международный туризм в ХХІ веке выступает значимым фактором развития мировой политики. Динамика роста туристских потоков и расширяюшаяся география путешествий дают основание определять туризм как часть общего процесса интернационализачии социально-экономических отномений. Во многих государствах индустрия туризма развивается довольно стабильно и эффективно. Политика стран должна быть ориентирована на извлечение максимальной выгоды из межсуународного туристского сотрудничества. Значимость международного туризма в политическом дискурсе подчеркивается созданием международно-правовых актов, регулирующих сферу туризма, а также различного уровня туристских организаций. Международный туризм применительно $\kappa$ мировой политике имеет особое преимущество в урегулировании разногласий между государствами. Отмечается роль туристской сферы в формировании имиджа и престижа страны. Участие России в международных туристских проектах служит источником культурного, социильного и экономического развития. Межгосударственные маршруты способствуют развитию культурного туризма, вписывающегося в политику устойчивого развития стран и регионов. Согласие иностранных партнеров на рассмотрение перспективных проектов по включению российских туристских дестинаций в культурные маршруты - положительная тенденция.

Цель - определение политической роли туризма в межгосударственных отношениях.

Метод или методология проведения работы: в статье использовались теоретический анализ, а также дескриптивный метод. 
Результаты: международный туризм становится инструментом преодоления негативного образа страны и оказывает влияние на имидж государства на международной арене.

Область применения результатов: результаты исследования могут служить основой для дальнейшего развития и усовершенствования межгосударственных связей по средствам туризма.

Ключевые слова: международный туризм; мировая политика; межгосударственный диалог; международные туристские проекты.

\section{TOURISM AS A POLITICAL INTERSTATE DIALOGUE}

\section{Matveevskaya A.S.}

International tourism in the 21st century is an important factor in the world politics' development. The growth of tourist flows and the worldwide scale of travels define tourism as part of the overall internationalization process of socio-economic relations. The tourism industry is developing quite stably and efficiently in many countries. National policies should be focused on obtaining the maximum benefit from international cooperation. The importance of international tourism in political discourse emphasizes the creation of international legal acts regulating the tourism industry, as well as different levels of tourist organizations. International tourism in world politics has a special advantage in resolving disagreements between states. The role of tourism in shaping the image and prestige of the country is noted. Russia 's participation in international tourism projects is a source of cultural, social and economic development. Interstate tours contribute to the development of cultural tourism into the sustainable development policies of countries and regions. A positive trend is the consent of the foreign partners on the inclusion of Russian tourist destinations in the perspective of cultural routes.

Purpose. Determination of the political role of tourism in interstate relations.

Methodology in article theoretical analysis and descriptive method were used. 
Results: international tourism in the XXI century is one of the most important factor in world politics.

Practical implications. The results of the research can serve as a basis for the further development and improvement of interstate relations by means of tourism.

Keywords: international tourism; world politics; interstate dialogue; international touristic programs.

За последние полвека международный туризм стал неотъемлемой частью жизни людей и превратился в одну из наиболее важных отраслей государственного сотрудничества [9]. Современная система международных отношений рассматривает туризм как средство развития дипломатического, культурного, экономического и социального взаимодействия. Международный туризм как стабильно развивающаяся часть экономики предполагает более тесную кооперацию между странами для разрешения межгосударственных проблем [13].

По данным UNWTO, в 2016 г. вклад туризма в мировую экономику составил $\$ 7,6$ трлн., что превышает $10 \%$ глобального ВВП. Туристская индустрия создает одно из 10 рабочих мест на планете. В 2016 г. в мире путешествовало 1,2 млрд. человек. Если исторически туристы чаще всего путешествовали между северными странами Земли, то сейчас наиболее быстрорастущие рынки располагаются в Африке, на Ближнем Востоке и в Азии, и в ближайшие десятилетия этот тренд сохранится [7]. Исследование Всемирного экономического форума (ВЭФ) показывают, что в промежутке между 2016 и 2026 гг. ожидается рост въездного туризма в Индию, Анголу, Уганду, Бруней, Таиланд, Китай, Мьянму, Оман, Мозамбик и Вьетнам [15].

В условиях растущей глобализации государства осознали важность кооперации и сотрудничества в сфере международного туризма [14]. Уже с середины XX века проводились международные форумы и конференции, на которых обсуждалось значение туризма, способы развития туристкой сферы. Итоги работы этих межго- 
сударственных встреч легли в основу ряда международных актов. Одним из таких международных документов является Общая резолюция Конференции ООН по международному туризму и путешествиям, принятая на заседании Организации Объединенных Наций в Риме в 1963 г. [5]. В резолюции рассматривались такие положения, как: растущее значение туризма в мире, организация технического сотрудничества стран, возможность контроля за туристскими потоками со стороны государства, а также помощь в развитии туристской сферы со стороны государств.

В 1980 г. на Филиппинах проводилась Всемирная конференция по туризму, в которой приняли участие более сотни делегаций из разных стран. В принятой Манильской декларации по мировому туризму дается определение понятию «туризм», как «деятельность, имеющая важное значение в жизни народов в силу непосредственного воздействия на социальную, культурную, образовательную и экономическую области жизни государств и на их международные отношения» [4].

Важным международно-правовым актом, регулирующим туристскую деятельность, является Хартия туризма, принятая и одобренная в 1985 г. на сессии Генеральной Ассамблеи Всемирной Туристской Организации. Хартия туризма включает в себя так называемый Кодекс туриста, а также предусматривает права людей на отдых и досуг, обозначает направление политики государства в отношении предоставления возможности путешествия своим гражданам [11]. Итогом развития международного сотрудничества в туристкой сфере явилась Межпарламентская конференция, проводимая в Гааге в 1989 г., в ходе которой была принята Декларация по туризму [3]. В документе изложены конкретные принципы и указания, которым надлежит следовать странам и организациям, занимающимся туристской деятельностью. Следует отметить, что одним из важных принципов в принятом документе является положение о соотношение туризма с окружающей средой и экологической обстановкой, что в свою очередь требует от государств немедленного решения экологических проблем и введения законодательства в от- 
ношении правил поведения туристов, путешествующих как внутри страны, так и за ее пределами. Таким образом, обозначенные выше международно-правовые акты заложили основу и продолжают служить опорными документами в проведении и развитии политики государств в отношении сферы туризма [8].

Стремительно развивающийся массовый туризм во многих государствах предопределил необходимость в формировании международных туристских связей, которые оформились в многочисленные организации и объединения международного уровня. Поддержка и содействие в развитии туристской индустрии, обмен мнениями и контактами специалистов из разных стран, совместные проекты по проведению туристской политики, а также совершенствование международных экономических отношений легли в основу целей создания таких организаций [12].

Первой такой организацией явился Международный конгресс официальных ассоциаций пропаганды туризма (1925г.). Позже были организованы Международный конгресс официальных туристских организаций (1927 г.), Международный союз официальных организаций пропаганды туризма (1930г.), которые явились базой, так сказать «предшественниками» основанного в 1947 г. Международного союза официальных туристских организаций (МСОТО), в состав которого входило уже 109 национальных туристских организаций. Необходимо отметить, что МСОТО являлось консультационным центром при Экономическом и Социальном совете ООН, однако не являлся правительственной организацией. Позже, уже в 1967 г. МСОТО был преобразован в межправительственный орган, сотрудничающий с такими международными организациями, как ООН по вопросам образования, науки и культуры (ЮНЕСКО), а также Всемирная организация здравоохранения (ВО3).

Ведущая на сегодняшний день организация в сфере туризма, а именно, Всемирная туристская организация была создана в 1975 г. из преобразованного МСОТО. В 2003 г. организация получила статус специализированного учреждения ООН, поэтому впоследствии 
стала называться Всемирной туристской организацией при Организации Объединенных Наций (ЮНВТО), членами которой сегодня являются 158 государств [2]. Деятельность Всемирной Туристской организации направлена на поощрение, помощь в развитии устойчивого и общедоступного туризма. Именно ЮНВТО способствует расширению туризма в мировом сообществе, а также поддержке сектора экономики, экологии и культуры в государствах, потому что именно эти сферы являются одними из основных во взаимодействии с туризмом.

Россия является активным участником межгосударственного диалога в индустрии туризма. Так, 23-я сессия Генеральной ассамблеи Всемирной туристкой организации ООН пройдет в 2019 г. в Санкт-Петербурге. В городе ежегодно проводится порядка 180 выставочно-ярморочных и 115 конгрессных мероприятий. СанктПетербург - один из крупнейших центров международного туризма в Европе [6]. В ноябре 2017 г. состоялся VI Санкт-Петербургский международный культурный форум - уникальное культурное событие мирового уровня. В рамках форума работала и секция туризма, на которой обсуждалось состояние и перспективы участие России в международном туризме.

Организованные в рамках форума мероприятия продемонстрировали разнонаправленное влияние политической ситуации на участие РФ в международном туризме. Так, на совместном заседании Координационных Советов по культуре и туризму при Министерстве культуры РФ активно обсуждались вопросы по участию страны в международных туристских проектах. Наибольший интерес у представителей российских регионов и иностранных гостей вызвало обсуждение перспектив участия России в «Культурных маршрутах» Совета Европы (Council of Europe).

Программы проекта выступают в качестве каналов для межкультурного диалога и содействуют расширению знаний о Европейской культурной идентичности и ее пониманию. «Культурные маршруты» являются частью широкой сети, которая способствует сотрудничеству между национальными, региональными и мест- 
ными властями и широким кругом ассоциаций и экономических субъектов. Программа, основанная на Культурных маршрутах, соответствует европейской стратегии по развитию международного культурного туризма. Уже существуют более тридцати сертифицированных Советом Европы Культурных маршрутов, которые охватывают различные направления европейской истории и наследия и способствуют пониманию разнообразия современной Европы. Россия участвует в таких как Ганзейские города (1991 г. - год сертификации), Путь викингов (1993 г.), Направления Наполеона (2015 г.). Участники форума поддержали подписание соглашения о включении российского бренда «Абрау Дюрсо» в енотуристские маршруты по Европе.

Влияние политических процессов, в том числе приведших к некоторой изоляции России в связи с организацией рядом государств против нее санкций не только в политической и экономической сферах, но и в сфере международных культурных контактов, вынуждают нашу страну принимать решения, призванные смягчить негативное влияние подобных ограничений. [10] В результате Ассоциация туроператоров России учредила комитет по импортозамещению. Данная Ассоциация представляет собой некоммерческое отраслевое объединение, которое защищает интересы туроператорского сообщества. В нее входят крупнейшие компании-туроператоры из различных регионов России.

Маршруты, утвержденные комитетом по импортозамещению разнообразны. Многие из них могут считаться как аттрактивные не только для отечественных, но и зарубежных туристов. Приведем лишь наиболее значимые в этом плане примеры: «Самоцветные истории Урала», «Янтарная мозаика», «Путешествие сквозь время: по следам Великого шелкового пути», «Чайный путь - врата Сибири».

В рамках IV Международной конференции «Евразийский вызов», прошедшей в ноябре 2017 г. в Санкт-Петербурге, участниками обсуждались вопросы развития международного туризма по «Великому Шелковому пути». В настоящее время это один из самых известных и развиваемых ныне международных туристских марш- 
рутов Евразии. Полагаем, что развитие туристских программ в рамках данного проекта может скорее заинтересовать такие страны как КНР, Узбекистан, Таджикистан, Афганистан, Казахстан, Турция, Италия. В пределах современной России маршруты Шелкового пути затрагивают лишь район Северо-Прикаспийский район.

Иначе может сложиться судьба другого международного проекта в сфере туристской индустрии - «Великого чайного пути». Исторический Великий чайный путь в XVI-XIX вв. соединял Азию и Европу, проходя по территории Китая, Монголии и России. Вместе с чаем по нему перевозили и многие другие товары. Протяженность главного сухопутного пути из Москвы до Пекина составляла в среднем (с учетом продвижения по разным участкам) около 8,5 тыс. верст. Спроектированы и реализуются программы по туристскому маршруту «Великий чайный путь» (протяженность 3тыс. км). Проект обслуживает поезд «Звезда Евразии» по Транссибирской магистрали. Туристам предлагается проехать по железной дороге из Китая до Уральских гор. Главные потенциальные участники тура - туристы из КНР. Информационный тур был организован весной 2017 г. Маршрут прошел через шесть крупнейших городов Сибири и Урала (Чита, Улан-Удэ, Иркутск, Красноярске, Новосибирск, Екатеринбург) [1].

Таким образом, сотрудничество и кооперация государств, контроль Всемирной туристской организации, национальных организаций по развитию туризма позволяют увеличить доходы государств, привлечь иностранные капиталы и частично переориентировать экономику и законодательство для привлечения иностранных туристов и последовательного развития сферы туризма. Успешное проведение дипломатических переговоров, поддержание стабильности мирного существования мирового сообщества способствуют расширению туристской сферы, что положительно влияет на экономику и развитие культурной сферы государств.

\section{Список литературы}

1. «Великий чайный путь» - предложение «РЖД тур». http://rzdtour. $\mathrm{com} / \mathrm{p}=2856$ (дата обращения: 27.11.2017). 
2. Всемирная туристская организация UNWTO. www.unwto.org/en/ content/who-we-are-0 (дата обращения: 21.11.2017).

3. Гаагская декларация по туризму. http://docs.cntd.ru/document/901737419 (дата обращения: 23.11.2017).

4. Манильская декларация по мировому туризму. http://docs.cntd.ru/ document/901813698 (дата обращения: 23.11.2017).

5. Общая резолюция Конференции ООН по международному туризму и путешествиям. http://docs.cntd.ru/document/901813699 (дата обращения: 21.11.2017).

6. «Петербург активизирует деятельность в сфере конгрессно-выставочного туризма» // Архив заседаний правительства от 20 декабря 2016 г. https://gov.spb.ru/press/government_meeting/103090/ (дата обращения: 27.11.2017).

7. Погодина В.Л. География туризма. Учебник / В.Л. Погодина, И.Г. Филиппова. М., Изд-во ИНФРА-М, 2015. 256 с.

8. Рагимов Т.С. Международное туристское право: тенденции и развитие // Журнал зарубежного законодательства и сравнительного правоведения. 2015. №4 (53). С. 603-608.

9. Растегаева Т.Е., Казаков И.С. Туризм как социально-экономическое явление современности // Наука Красноярья. 2016. 1(24). C.107-118.

10. Социально-гуманитарные проблемы современности: политика, социум, культура: монография / А.Ю. Николаева, Е.И. Лобынева, Ж.С. Головко [и др.]. Красноярск, 2012. 256 с.

11. Хартия туризма и кодекс туриста. http://www.keyb.ru/info/269/ (дата обращения: 21.11.2017).

12. Bettiza, G., (2014) Civilizational analysis in international relations: mapping the field and advancing a "civilizational politics" line of research. International Studies Review, 16 (1), 1-28. doi: 10.1111/ misr. 12100

13. Daenekindt, S.A., de Koster, W.A., \& Van der Waal, J.A. (2017). How people organise cultural attitudes: cultural belief systems and the populist radical right. West European Politics, 40 (4), 791-811. http:// www.tandfonline.com/doi/full/10.1080/01402382.2016.1271970 
14. Petito F. (2016). Dialogue of civilizations in a multipolar world: toward a multicivilizational-multiplex world order. International Studies Review, 18 (1). 78-91. http://dx.doi.org/10.1093/isr/viv030

15. The Travel and Tourism Competitiveness Report [Электронный peсурс]. Режим доступа: http://reports.weforum.org/travel-and-tourismcompetitiveness-report-2017/ (дата обращения: 23.11.2017).

\section{References}

1. "The Great Tea Way" - the proposal "RZD tour". http://rzdtour. $\mathrm{com} / \mathrm{p}=2856$

2. World Tourism Organization UNWTO. www.unwto.org/en/content/ who-we-are- 0

3. The Hague Declaration on Tourism. http://docs.cntd.ru/document/901737419

4. Manila Declaration on World Tourism. http://docs.cntd.ru/document/901813698

5. General resolution of the United Nations Conference on International Tourism and Travel. http://docs.cntd.ru/document/901813699

6. Archive of government meetings of December 20, 2016. https://gov.spb. ru/press/government_meeting/103090/

7. Pogodina V.L., Filippova I.G. Geografiya turizma [Geography of tourism]. M., Izd-vo INFRA-M, 2015. 256 p.

8. Ragimov T.S. Zhurnal zarubezhnogo zakonodatel'stva i sravnitel'nogo pravovedeniya. 2015. №4 (53), pp. 603-608.

9. Rastegaeva T.E., Kazakov I.S. Nauka Krasnoyar'ya. 2016. 1(24), pp. 107-118.

10. Nikolaeva A.Yu., Lobyneva E.I., Golovko Zh.S. [et al.] Sotsial'no-gumanitarnye problemy sovremennosti: politika, sotsium, kul 'tura [Social and humanitarian problems of our time: politics, society, culture]. Krasnoyarsk, 2012. 256 p.

11. Charter of Tourism and the tourist code. http://www.keyb.ru/info/269/

12. Bettiza, G., (2014) Civilizational analysis in international relations: mapping the field and advancing a "civilizational politics" line of research. International Studies Review, 16 (1), 1-28. doi: 10.1111/misr.12100 
13. Daenekindt S.A., de Koster W.A., \& Van der Waal J.A. (2017). How people organise cultural attitudes: cultural belief systems and the populist radical right. West European Politics, 40 (4), 791-811. http://www. tandfonline.com/doi/full/10.1080/01402382.2016.1271970

14. Petito F. (2016). Dialogue of civilizations in a multipolar world: toward a multicivilizational-multiplex world order. International Studies Review, 18 (1). 78-91. http://dx.doi.org/10.1093/isr/viv030

15. The Travel and Tourism Competitiveness Report. http://reports.weforum.org/travel-and-tourism-competitiveness-report-2017/

\section{ДАННЫЕ ОБ АВТОРЕ}

Матвеевская Анна Сергеевна, старший преподаватель кафедры «Мировой политики», кандидат географических наук Санкт-Петербургский государственньй университет Университетская наб., 7/9, г. Санкт-Петербург, 199034, Российская Федерация

annamatveevskaya@mail.ru

\section{DATA ABOUT THE AUTHOR}

Matveevskaya Anna Sergeevna, Senior Lecturer «World Politics», Candidate of Geographic Sciences

St. Petersburg Stat University

7/9, Uniersitetskaya nab., St. Petersburg, 199034, Russian Federation

annamatveevskaya@mail.ru

SPIN-code: 9840-7449

ORCID: 0000-0002-2056-5557

ResearcherID: O-5001-2014 